\title{
PROBLEMATIKA PEMBELAJARAN KITAB KUNING DI PESANTREN PUTRA ALKHAIRAAT PUSAT PALU
}

\author{
PROBLEMATICS LEARNING OF KITAB KUNING \\ AT PESANTREN PUTRA ALKHAIRAAT PUSAT PALU
}

\author{
Syarifuddin \\ Peneliti Balai Penelitian dan Pengembangan Agama Makassar \\ Alamat Kantor: Jl. AP. Pettarani Nomor 72 Makassar \\ Email: syarifuddinamir84@yahoo.com
}

Naskah diterima tanggal 6 April 2020, Naskah direvisi tanggal 29 April 2020, Naskah disetujui tanggal 9 Juni 2020

\begin{abstract}
Abstrak
Kitab Kuning merupakan salah satu rukun dari beberapa rukun pesantren. Oleh karena itu, pembelajaran Kitab Kuning sesuatu yang mutlak dilaksanakan oleh setiap pesantren. Namun faktanya, banyak pesantren yang tidak melaksanakan pembelajaran kitab Kuning. Penelitian ini merupakan penelitian kualitatif deskriptif yang memotret problem pembelajaran kitab kuning yang dihadapi oleh Pesantren Putra Alkhairaat Pusat Palu. Kajian ini menemukan bahwa Kitab Kuning diajarkan secara langsung di Pesantren Putra Alkhairaat Pusat Palu masih pada taraf kitab tingkat dasar seperti Matan Aljurumiyah, Nahwu al-Wadhih, Aqidah al-'Awwam, Risalah al-Jami'ah, Matan Safinah al-Naja dan Muqaddimah Hadramiyyah. Realitas tersebut disebabkan karena minimnya tenaga pengajar. Sistem kaderisasi tenaga pengajar yang tidak berjalan juga berkorelasi dengan problem pendanaan dalam operasional pesantren yang lebih mengandalkan iuran pembayaran dari santri. Sehingga pihak pesantren kesulitan mencari tenaga pengajar yang bisa mengabdikan waktu dalam mengajar kitab kuning. Disisi lain secara metodologis, masalah yang dihadapi yaitu tidak adanya konsep kurikulum dan silabus yang baku yang menjadi acuan wajib dalam pembelajaran kitab kuning.
\end{abstract}

Kata Kunci: santri, kitab kuning, pesantren alkhairaat, pembelajaran

\begin{abstract}
The Kitab Kuning is one of the several pillars of the Islamic Boarding School. Therefore, learning the Kitab Kuning something that is absolutely implemented by each Islamic Boarding School. But in fact, many Islamic Boarding School don't study the Kitab Kuning. This research is a descriptive qualitative study that portrays the learning problems of the learning Kitab Kuning in the Islamic Boarding School (Pesantren) Putra Alkhairaat Pusat Palu. This study found that the Kitab Kuning was taught directly at the Pesantren Putra Alkhairaat Pusat Palu still at the level of basic books such as Matan Aljurumiyah, Nahwu al-Wadhih, Aqidah al-'Awwam, Risalah al-Jami'ah, Matan Safinah al-Naja and Muqaddimah Hadramiyyah. This reality is caused because the teachers is very few. The regeneration system of teachers that is not running also correlates with funding problems in Islamic Boarding School operations which expect payment contributions from students. So that Pesantren Putra Alkhairaat Pusat Palu have difficulty finding teachers who can dedicate their time in teaching the Kitab Kuning. Besides on the other methodologically perspective, the are many problems is the are not a standard curriculum and syllabus concept that becomes a primary reference in learning the Kitab Kuning.
\end{abstract}

Keywords: student of islamic boarding school, kitab kuning, pesantren alkhairaat, learning

\section{PENDAHULUAN}

$\mathrm{P}$ esantren adalah termasuk lembaga pendidikan keagamaan tertua di negeri ini. Riwayat histori pesantren oleh berbagai pakar tidak bisa dipisahkan dengan kajian kitab kuning. Oleh karena, dalam berbagai definisi tentang pesantren, kajian kuning menjadi salah satu unsur dari beberapa unsur di samping kiai, santri, masjid dan asrama. Secara historis, kajian kitab 
kuning dikenal sebagai tradisi Nahdatul Ulama sekaligus menjadi prasyarat pengakuan keulamaan seseorang. (Burhanuddin 2012, 358-59) menyebutkan pengalaman Zaifuddin Zuhri dalam sebuah forum kajian kitab kuning. Lewat forum tersebut, tingkat keulamaan seseorang ditentukan dari kemampuannya dalam menjelaskan setiap kalimat dari kitab yang dikaji. Oleh karena itu, pesantren yang dikenal sebagai lembaga produsen ulama menjadikan kitab kuning sebagai bagian yang tak terpisahkan dalam sistem kurikulumnya. Di Pesantren, kitab kuning biasanya diajarkan oleh kiai. Sebutan kiai sendiri merupakan gelar yang diberikan oleh masyarakat kepada seorang ahli agama Islam atau menjadi pemimpin pesantren dan mengajarkan kitab-kitab Islam klasik kepada santrinya (Dhofier 2011, 93).

Menurut (Baso 2012, 135), tradisi kajian kitab ini sebenarnya sudah berlangsung sejak berabad-abad yang lalu dan disebutkan bahwa tradisi peradaban Islam di nusantara adalah tradisi peradaban kitab. Ini dibuktikan dengan adanya koleksi naskah kitab ulamaulama Banten. Adalah Sultan Banten Maulana Muhammad cucu dari Sunan Gunung Jati, yang memberikan perhatian besar terhadap dunia kitab. Ia menggelar wakaf kitab untuk pesantren. Di samping itu, ia juga mendirikan pesantren di luar istana. Untuk menguatkan pendapatnya, ia juga memaparkan koleksi Kraton Surakarta yang juga dipelopori kalangan pesantren (Baso 2012).

Seiring dengan perjalanan waktu, kurikulum di pesantren tidak hanya mengacu pada kajian kitab kuning. Namun lebih dari itu, banyak pesantren sudah mengakomodir kurikulum dari Kementerian Pendidikan dan Kementerian Agama (madrasah). Di samping itu, pesantren di Nusantara juga mengalami transformasi dalam berbagai bentuk. Sehingga kajiannya bukan saja terkait pada kajiankajian keagamaan, namun lebih luas pada kajian non agama. Pada akhirnya, bisa ditemukan di beberapa tempat pesantren berbasis, teknik mesin, agrobisnis, kebaharian, dan lain sebagainya. Akibatnya, kajian kitab kuning bukan menjadi kajian yang paling urgen di pesantren. Bahkan banyak pesantren yang sudah tidak mengajarkan kitab kuning.
Dengan kata lain, pesantren tersebut tidak jauh beda dengan madrasah pada umumnya kecuali hanya santri yang diasramakan. Sehingga, muncullah istilah "madrasah berasrama". Padahal, menurut Peraturan Menteri Agama nomor 13 Tahun 2014 tentang Pendidikan Keagamaan Islam pasal 5 menyebutkan bahwa "Pesantren wajib memiliki unsur-unsur pesantren yang salah satunya adalah pengajian atau kajian kitab kuning atau dirasah islamiyyah dengan pola mu'allimin.

Secara kuantitas, pertumbuhan pesantren yang terdaftar di Kementerian Agama bertambah dari tahun ke tahun. Data tahun 1977 menyebutkan bahwa jumlah pesantren masih pada kisaran 4.195 buah dengan jumlah santri sekitar 677.394 orang. Jumlah ini kemudian meningkat tajam dua dasawarsa kemudian tepatnya tahun 1997 dengan kenaikan jumlah pesantren sekitar 224 $\%$ atau 9.388 buah, kenaikan jumlah santri mencapai $261 \%$ atau 1.770 .768 orang (Umar 2014, 26). Data tahun 2016 Kementerian Agama Pusat, tercatat 28.194 dengan 13.901 diantaranya yang hanya mengadakan pengajian kitab kuning (Salafiyah) dan 14.293 yang mengombinasikan dengan kurikulum lainnya. Lembaga pesantren yang hanya mengadakan pengajian kitab kuning lebih banyak tersebar di pulau jawa seperti Jawa Barat, Banten, Jawa Tengah dan Jawa Timur. Sementara untuk 10 provinsi di wilayah timur hanya 53 pesantren. Pesantren-pesantren tersebut membina sekitar 4.290.626 santri (Kementerian Agama RI 2017).

Data tersebut di atas membuktikan kepercayaan masyarakat terhadap institusi pesantren sebagai satu-satunya lembaga tempat mempelajari dan mendalami ajaran agama (tafaqquh fi al-din), penghasil ulama, da'i, muballig dan ustaz. Di samping itu, pesantren masih dianggap sebagai "bengkel manusia" paling efektif dalam mengatasi kenakalan anak yang biasanya sudah tidak mampu lagi ditangani oleh orang tuanya.

Secara garis besar, (Umar 2014) membagi pesantren berdasarkan tipe pendidikannya sebagai berikut: 1). Pesantren yang menyelenggarakan pendidikan formal dengan menerapkan kurikulum nasional. 
Lembaga formal tersebut bisa berupa lembaga keagamaan seperti Perguruan Tinggi Agama, MA, MTs, dan MI ataupun sekolah umum seperti SD, SMP, SMA dan Perguruan Tinggi Umum. 2). Pesantren yang menerapkan kurikulum keagamaan dan ilmu umum namun tidak mengikuti kurikulum nasional seperti Pesantren Gontor Ponorogo. 3). Pesantren yang hanya mengajarkan ilmu agama umunnya mengacu pada kajian kitab kuning. Biasanya tipe pesantren seperti ini disebut Pesantren Salafiyah. 4). Pesantren yang hanya sekedar menjadi tempat pengajian.

Pembagian tipologi pesantren yang hampir mirip dikemukakan oleh Amin Haedari sebagaimana yang dikutip oleh Mardiyah. Yang membedakan hanya pada tipe ketiga yaitu pesantren yang mendirikan Madrasah Diniyah (Mardiyah 2013, 446). Kemungkinan yang dimaksudkan dari tipologi ketiga tersebut adalah Pesantren Salafiyah menggunakan sistem madrasi (klasikal), dengan kurikulumnya sebagian besar adalah kajian kitab kuning. Dari keempat tipe tersebut, tampaknya tipe yang ketiga dan keempat yang masih memanfaatkan tradisi pengajian kitab dalam sistem pendidikannya. Hanya secara kuantitas, tipe ini sangat sedikit dan kurang diminati oleh masyarakat secara umum. Hal berbanding terbalik dengan tipe pertama dan kedua yang memadukan antara kajian kitab kuning dan kurikulum nasional, jumlah kuantitasnya lebih banyak. Hal ini disebabkan kecenderungan masyarakat menyekolahkan anaknya pada lembaga pendidikan yang menghasilkan ijazah pendidikan formal yang diakui oleh pemerintah. Kenyataan ini berbeda dengan pesantren tipe ketiga dan keempat, yang memiliki ijazah tapi tidak diakui bahkan ada yang tidak menggunakan ijazah. Kalaupun ada usaha untuk memperoleh ijazah formal yang diakui, biasanya para santri diikutkan ujian persamaan (mu'adalah) pada lembaga lainnya. Pada prosesnya, ujian mu'adalah sendiri tidaklah semudah yang dibayangkan oleh pihak pesantren. Akhirnya, banyak pesantren mengutamakan kurikulum pemerintah dibanding kajian kitab kuning.

Oleh karena itu, kemungkinan negatif yang muncul, banyak masyarakat yang memasukkan anaknya ke pesantren tujuannya bukanlah murni "nyantri" tet api ingin sekolah dengan mendapatkan ijazah formal agar kelak dapat memperolah pekerjaan (Mardiyah 2013). Yang lebih parah apabila ada yang menganggap "nyantri dengan dengan tradisi sarungan dan ngaji kitab adalah tradisi kolot yang ketinggalan zaman. Akibatnya, pesantren diprediksi semakin sulit melahirkan ulama yang kompeten dalam ilmu agama. Padahal, harapan pemerintah dan masyarakat bahwa pesantrenlah satu-satunya lembaga autoritatif yang melahirkan ulama.

Berdasar pada realitas tersebut di at as, maka kajian ini akan menelusuri problem pembelajaran Kitab Kuning di Pesantren Putra Alkhairaat Pusat Palu. Alasan pemilihan lokus ini berdasarkan pada pertimbangan historis bahwa pesantren ini sejak dahulu kala yang merupakan bagian dari Perguruan Islam Alkhairaat yang dirintis oleh Sayyid Idrus Salim Al-Jufry, telah menghasilkan banyak ulama yang tersebar ke bagian tengah hingga utara Pulau Sulawesi.

Berdasarkan dari latar belakang tersebut, masalah pokok penelitian ini yaitu bagaimana pembelajaran kitab kuning di Pondok Pesantren Putra Alkhairaat Pusat Palu? Masalah penelitian ini kemudian dituangkan ke dalam rumusan masalah yaitu: 1). Apa jenis kitab kuning yang diajarkan di Pondok Pesantren Putra Alkhairaat Pusat Palu? 2). Bagaimana mekanisme pembelajaran Kitab Kuning di Pondok Pesantren Putra Alkhairaat Pusat Palu? dan 3). Bagaimana problem dan solusi yang dihadapi dalam pembelajaran kitab kuning di Pondok Pesantren Putra Alkhairaat Pusat Palu?

Penelitian ini bertujuan menjawab permasalahan di atas yaitu: Mengetahui jenis kitab kuning yang diajarkan di Pondok Pesantren Putra Alkhairaat Pusat Palu, Mengetahui memahami dan mendalami mekanisme pembelajaran Kitab Kuning di Pondok Pesantren dan mendeskripsikan problem dan solusi yang dihadapi dalam pembelajaran Kitab Kuning di Pondok Pesantren.

Definisi Kitab Kuning dalam penelitian ini yaitu berdasarkan pada Perat uran Menteri Agama Nomor 13 Tahun 2014 tentang Pendidikan Keagamaan Islam Pasal 1 Ayat 3 yaitu; kitab-kitab klasik atau kitab keislaman yang berbahasa Arab yang menjadi rujukan di Pondok Pesantren. 


\section{TINJAUAN PUSTAKA}

Salah satu referensi yang banyak dikutip oleh peneliti terkait kajian Kitab Kuning di Pesantren adalah karya Martin Van Bruinessen "Kitab Kuning, Pesantren dan Tarekat". Dalam buku tersebut, pesantren merupakan pendidikan Islam tradisional khas Nusantara. Dalam praktiknya, terpengaruh faktor dari luar khususnya dari Mekah. Salah satu pengaruh itu adalah kajian kitab kuning yang disebut juga sebagai (kutub mu'tabarah). Banyak kitab kuning yang berbahasa Arab diajarkan di Indonesia bukan ditulis di Indonesia tetapi di Mekah walaupun penulisnya adalah ulama Indonesia seperti Nawawi al-Bantani (Bruinessen 2015, 90). Lebih lanjut, ia menyebutkan kitab-kitab yang diajarkan di pesantren mulai dari penulis, proses penerbitan, jenis serta jumlahnya. Menurutnya, ratusan kitab kuning yang berbahasa Arab yang diajarkan, sebagian besarnya mengacu pada kajian fikih yang berorientasi pada Mazhab Syafi'i (Bruinessen 2015).

Pada tahun 1994, telah terbit buku bunga rampai hasil penelitian dari para peneliti Balai Penelitian Lektur Keagamaan Ujung Pandang (kini Balai Penelitian dan Pengembangan Agama Makassar) yang berjudul transformasi kelekturan pesantren di Sulawesi Selatan. Kajian ini mengambil lokus di lima pesantren, yaitu: Pesantren As'adiyah Sengkang (Abd. Kadir M), Pesantren Manahil Ulum Kaballangan Pinrang (Muhammad As'ad), Pesantren Al Urwatul Wustqa Sidrap (Abd. Kadir Ahmad), Pesantren Babul Khaer Bulukumba (M. Alwy Amien), dan Pesantren Darul Istiqamah Maros (Matugengkeng). Kelima pesantren tersebut merupakan pesantren yang mengombinasikan antara kurikulum khas kepesantrenan berupa kitab kuning kurikulum Departemen Agama dan Departemen Pendidikan. Kajian ini menyebutkan beberapa kitab kuning yang dikaji di pesantren. Di Pesantren As'adiyah Sengkang disebutkan bahwa kitab yang diajarkan yaitu materi pelajaran di kelas dipadukan antara kajian kitab dengan buku paket khusus madrasah. Misalnya, untuk pelajaran Fikih ditingkat Madrasah Tsanawiyah, bahan ajar yang dijadikan pegangan guru dan santri adalah Buku Paket Fikih untuk Madrasah Tsanawiyah, Kifayatul Akhyar, Tanwirul Qulub dan Fiqh Mawaris. Hanya saja, implementasi pembelajaran buku dan kitab tersebut di atas tidak disebutkan secara eksplisit. Begitu pun di mata pelajaran lainnya selalu dipadukan antara buku kurikulum Departemen Agama dan kitab kuning. Di samping pembelajaran di kelas, beberapa kitab juga diajarkan dalam sistem halakah di masjid yaitu: Tafsir Jalalayn, Riyadhul Salihin, Sahihu Bukhari, Tanwirul Qulub, Fathul Mu'in, Irsyad Ibad. Al Muhazzab Mau'izah al-Mu'minin dan Syarh al-Hikam (M 1994, 36-38). Kasus yang sama juga terjadi pada pesantren lainnya, misalnya Pesantren Manahilul Ulum Kaballangan Pinrang yang mengombinasikan kurikulum Departemen Agama, Departemen Pendidikan, dan Khas kepesantrenan yang berbasis kitab kuning. Hanya saja perbedaannya, buku atau kitab pegangan ditentukan sendiri tanpa memadukan buku paket madrasah dengan kitab kuning (As'ad 1994, 76-77).

Pada tahun 2011, Balai Penelitian dan Pengembangan Agama Makassar mengadakan penelitian Implementasi Pengajian Kitab Pada Pondok Pesantren di Kawasan Timur Indonesia. Sebagian dari kajian telah diterbitkan dalam buku bunga rampai yang berjudul "Reinversi Kurikulum dan Pembelajaran Pendidikan Agama dan Keagamaan" tahun 2011. Kajian yang diterbitkan yaitu tulisan (Mujizatullah 2011, 171-256) di Pesantren Mambaush Shalihin Haramain Palu, (Rosdiana 2011, 343-92) di Pesantren Ulumul Quran Fatimah Azzahra Pambusuang Polman dan (Arsyad 2011, 393448) di Pesantren Salafiyah Parappe Campalagian Polman. Ketiga pesantren yang menjadi lokus penelitian merupakan tipe pesantren tradisional (salaf) yang secara tradisi, kurikulumnya lebih difokuskan pada pembelajaran kitab kuning. Artikel lain terkait kitab kuning juga terdapat dalam jurnal AlQalam, yang mengulas tentang isu kebangsaan dalam materi pembelajaran kitab kuning di Pesantren PKP Manado (Subair 2019). Secara umum, kajian tersebut memaparkan proses pembelajaran kitab kuning dengan mengacu sistem kelas atau 
tabaqah (tingkatan). Namun, belum memaparkan secara eksplisit problem yang dihadapi berupa kurikulum, metodologis, waktu, dan lainnya serta pemecahannya.

Dalam konteks kajian ini, Kitab Kuning merupakan salah satu instrumen yang bisa dimanfaatkan sebagai sumber belajar. Secara bahasa, pemanfaatan bermakna menjadikan ada manfaat dengan kata lain adalah proses, cara, perbuatan memanfaatkan (Pusat Bahasa Departemen Pendidikan Nasional 2008, 982). Sementara menurut (E. Mulyasa 2008, 48) bahwa:

"Sumber belajar dapat dirumuskan sebagai segala sesuatu yang dapat memberikan kemudahan kepada siswa dalam memperoleh sejumlah informasi, pengetahuan, pengalaman dan keterampilan dalam proses belajar mengajar."

Sedangkan menurut Sudjana dan Rivai sebagaimana dikutip oleh Abu Muslim, mengatakan bahwa "sumber belajar adalah suatu daya yang bisa dimanfaatkan guna kepentingan proses belajar mengajar baik secara langsung maupun tidak langsung, sebagian atau keseluruhan". Dari definisi ini bisa dimaknai bahwa sumber belajar adalah segala sesuatu yang baik yang didesain menurut sifatnya dapat dimanfaatkan dalam kegiatan pembelajaran (Muslim 2016, 264). Selanjutnya, pemanfaatan sumber belajar dalam proses pembelajaran sebagaimana dikutip dari Yunanto adalah aktivitas, cara dan proses dalam memanfaatkan sumber belajar untuk pencapaian tujuan pembelajaran yang ditetapkan untuk memperoleh hasil belajar yang maksimal (Muslim 2016). Pemanfaatan kitab kuning di pesantren yang merupakan salah satu sumber belajar yaitu bertujuan memberikan pengetahuan yang mendalam bagi santri dalam dalam mencapai tujuan utama yaitu memahami ajaran agama (tafaqquh fi al-din).

Sementara itu, kitab kuning secara literal dimaknai sebagai kitab yang berwarna kuning. Di Timur tengah kitab-kitab sejenis biasanya disebut sebagai kitab klasik (alkutub al-qadimah). Kitab jenis ini memiliki ciri-ciri seperti: 1. Penyusunannya dari yang lebih besar terinci ke yang lebih kecil seperti kitabun, babun, faslun, far' un dan seterusnya, 2. Tidak menggunakan tanda baca seperti titik, koma, tanda seru, dan lain sebagainya 3.
Selalu digunakan idiom tertentu seperti almazhab, al-aslah, al-rajih, wa allahu a'lam bi shawab. (Qamar, n.d., 127). Selanjutnya, kitab kuning yang biasanya diajarkan di pesantren terbagi ke dalam tiga jenis yaitu matan, syarah (penjelasan/komentar), hasyiah (komentar atas komentar). Definisi yang lebih luas tentang kitab kuning disebutkan dalam Peraturan Menteri Agama Nomor 13 tahun 2014 pasal 1 (3) bahwa kitab kuning adalah kitab keislaman yang berbahasa Arab yang menjadi rujukan tradisi keilmuan di pesantren. Definisi ini lebih umum tanpa ciri-ciri tersebut di atas.

Secara garis besar, kitab kuning yang diajarkan di pesantren digolongkan ke dalam jenis cabang ilmu pengetahuan agama Islam: 1. Nawhu (Sintax) dan Sharaf (Morfologi), 2. Fiqh, 3. Usul Fiqh, 4. Hadis, 5. Tafsir, 6. Tauhid, 7. Tasawuf dan Etika, dan 8. Cabangcabang lainnya seperti Sejarah (Tarikh) dan Balagah (Dhofier 2011). Sistem belajar mengajar kitab kuning di pesantren yang selama ini dikenal ada dua, yaitu: pertama, sistem sorogan (talaqqi) yang dikenal juga sebagai sistem individual (Dhofier 2011). Kedua, sistem bandongan/wetonan (halaqah) at au sistem kelompok. Kedua sistem tersebut di atas dikenal juga dengan sistem tradisional. Seiring dengan perjalanan waktu disertai dengan perkembangan sistem pembelajaran, pesantren pun kini mengadopsi sistem pembelajaran modern dengan sistem madrasi (klasikal) yaitu pembelajaran yang disusun dalam bentuk kelas dengan kurikulum yang sudah ditentukan oleh pihak pesantren (Qamar, n.d.).

\section{METODOLOGI PENELITIAN}

Penelitian ini merupakan penelitian kualitatif deskriptif yang memotret problem pembelajaran kitab kuning di Pesantren Putra Alkhairaat Pusat Palu. Data primer penelitian berupa data yang berkaitan dengan pembelajaran kitab kuning di pesantren Putra Alkhairaat Pusat Palu. Sedangkan data sekunder yaitu data pendukung lainnya. Sumber data tersebut berasal dari pimpinan pesantren, kiai, ustaz, santri dan lain sebagainya. Dalam penelitian ini, digunakan metode pengumpulan data yang biasanya digunakan dalam penelitian kualitatif yaitu wawancara (Cresswell 2014, 189). Teknik 
wawancara dilakukan dengan informan dalam rangka menelusuri dan mendapatkan informasi Pembelajaran Kitab Kuning di pesantren. Teknik ini dipadukan dengan observasi dan dokumentasi agar data yang diperoleh lebih akurat. Penelitian ini merupakan penelitian kualitatif. Oleh karena itu peneliti sendiri menjadi instrumen utama (Sugiyono 2010). sehingga, analisis data dilakukan oleh peneliti sendiri mulai proses penelitian dilaksanakan hingga penulisan laporan atau artikel.

\section{PEMBAHASAN}

\section{Profil Pesantren Putra Alkhairaat Pusat Palu}

Ketika menyebut nama pesantren di Sulawesi Tengah, maka yang terngiang di pikiran kita adalah nama Alkhairaat dengan nama besar dan sejarahnya yang panjang. Alkhairaat sendiri awalnya adalah lembaga pengajian (kemudian berubah menjadi "Perguruan Islam Alkhairaat") yang didirikan oleh Al-'Allamah al-Habib Sayyid Idrus bin Salim Al-Jufri yang dikenal juga dengan sebutan Guru Tua (Kambay 1992, 1). Dalam perkembangan selanjutnya, nama Alkhairaat kemudian berkembang menjadi organisasi masyarakat yang salah satu fungsinya membina lembaga pendidikan. Kini, Alkhairaat membina lebih dari 49 pesantren yang tersebar di Nusantara serta ratusan madrasah/sekolah serta perguruan tinggi Alkhairaat ("Lembaga Pendidikan Dan Dakwah Islam Alkhairaat," n.d.).

Pesantren Putra Alkhairaat Pusat Palu merupakan lembaga pendidikan keagamaan di bawah naungan Organisasi Alkhairaat yang berpusat di Kota Palu. Inisiator pendirian pesantren ini adalah Habib Muhamad bin Idrus Salim Aljufri (Putra Guru Tua) sekaligus menjadi pimpinan pertama. Pesantren ini sendiri menjadi perintis lahirnya pesantren Alkhairaat di seantero nusant ara yang tersebar di Pulau Sulawesi, Kalimantan hingga ke Kepulauan Maluku.

Pesantren Putra Alkhairaat Pusat beralamat di jalan Mangga nomor 31-33 di Kota Palu tidak jauh dari kantor pusat PB Alkhairaat. Pesantren ini ini diresmikan pada tahun 1975 oleh Habib Muhammad bin Idrus
Aljufri putra dari Guru Tua. Kepemimpinan kemudian dilanjutkan oleh KH. Rustam Arsyad dan dilanjutkan oleh Habib Abdillah bin Muhammad bin Idrus Aljufri (cucu Guru Tua) hingga ia wafat tahun 2006. Pada masanya, ia menambahkan kata "Putera" sebelum kata "Alkhairaat". Tonggak kepemimpinan kemudian dilanjutkan Habib Idrus bin Abdillah Al-Jufri hingga kini.

Visi yang diusung Pesantren Putra Alkhairaat Pusat adalah berdasarkan pada ayat Alquran QS. Al-Tawbah/9 ayat 122:

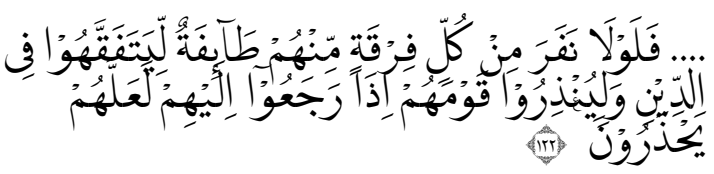

Terjemahnya: “...... Mengapa sebagian dari setiap golongan di antara mereka tidak pergi untuk memperdalam pengetahuan agama mereka dan untuk memberi peringatan kepada kaumnya apabila mereka telah kembali, agar mereka dapat menjaga dirinya."

Untuk mewujudkan visi tersebut, dirumuskan misi sebagai berikut; 1). Menjadikan santri Pesantren Putra Alkhairaat beriman, bertakwa, dan berakhlakul karimah, 2). Memiliki pengetahuan agama dan umum yang cukup, 3). Membekali Hafalan Alquran, Hadis dan Bahasa Arab.

Model Pesantren Putra Alkhairaat Palu merupakan pesantren kombinasi, dengan membina satuan pendidikan berupa SMP yang berkordinasi langsung dengan Dinas Pendidikan Kota Palu. Pilihan kombinasi dengan Pendidikan formal tersebut merupakan lanjutan dari cita-cita Guru Tua sejak beliau merintis Perguruan Alkhairaat dengan menggabungkan antara ilmu agama dan ilmu umum (Tim Penulis 2014, 65). Awalnya, pesantren membina juga Madrasah Tsanawiyah (MTs). Hanya saja jumlah santri yang dari tahun ke tahun semakin berkurang serta dengan pertimbangan bahwa SMP lebih dulu izin operasionalnya, maka sejak tahun 2016, lembaga MTs yang dibina untuk sementara dibekukan (dileburkan) ke SMP 2 Alkhairaat dengan mengacu pada sistem SMP berbasis pesantren. Pilihan ini merupakan wujud kekhawatiran terkait dengan jumlah rombongan belajar yang berdampak pada sertifikasi guru dan akreditasi lembaga. 
Pembekuan MTs tersebut berakibat negatif pada urusan administrasi di Kementerian Agama. Sejak tahun 2016, Pesantren Putra Alkhairaat Pusat tidak pernah lagi memutakhirkan datanya di pendat an Emis Pondok Pesantren. Akibatnya, saat ini data pesantren Alkhairaat tidak terdaftar di Aplikasi Data Emis Kementerian Agama. Kenyataan ini diakibatkan karena bagian tata usaha yang mengurus bidang administrasi di pesantren hanya terdapat di SMP, yang secara struktural berkordinasi ke Dinas Pendidikan. Sementara, lembaga pesantren tidak memiliki tenaga administrasi yang resmi. Alasan lain yang menjadi pilihan pengurus untuk memilih membina SMP adalah alasan yang dilematis, karena madrasah dianggap tidak cukup mumpuni untuk menanamkan ajaran agama secara mendalam. Menurut Muhammad Rumi:

\begin{abstract}
"Mendalami ajaran agama haruslah dari sumbersumber yang berbahasa Arab atau dikenal dengan Kitab Kuning. Oleh karena itu, di samping belajar dengan materi kurikulum Dinas Pendidikan, pesantren ini juga mempelajari muatan agama di kelas dengan berbasis pada kitab berbahas Arab seperti fikih. Kami memilih membina SMP di bawah Dinas Pendidikan karena kurikulum Kementerian Agama tidak mampu mencetak ahli agama. Di satu sisi, alumni SMP lebih bisa bersaing di berbagai bidang dibanding alumni madrasah." (Wawancara, Muhammad Hadi Rumi, Pengurus Operasional Pesantren Putra Alkhairaat Pusat Palu di Palu, 10/3/2018).
\end{abstract}

Dalam operasionalnya, Pesantren Pusat Alkhairaat yang dipimpin oleh pimpinan harian yakni Habib Thalib Aljufri, terletak di pusat kota Palu tepatnya di Jalan Mangga. Asrama putra berdampingan dengan kompleks pesantren putri di Jalan Sis Aljufri. Ditinjau dari sarana dan prasarana pun yang dimiliki cukup lengkap. Misalnya, pesantren memiliki bangunan masjid yang cukup sebagai sentra kegiatan santri sekaligus sebagai salah satu rukun pondok. Letaknya berada di samping pintu utama sehingga masyarakat sekitar pun bisa ikut salat berjama'ah berbaur dengan santri. Lokasi yang sangat strategis serta nama besar Alkhairaat yang sudah mengakar di masyarakat menjadi modal untuk menarik minat masyarakat untuk memasukkan anaknya di pesantren.

Pada tahun pelajaran 2017/2018, Pesantren membina santri sebanyak 72 orang dari tingkat SMP Sementara sisanya santri tingkat Aliyah/SMA sebanyak 11 orang yang belajar di SMA/MA Alkhairaat (binaan Pengurus Besar Alkhairaat) di lokasi yang tidak jauh dari pesantren. Sehingga secara keseluruhan, Pesantren Alkhairaat Putra memiliki santri sebanyak 82 orang. Semua santri wajib tinggal di asrama untuk mengikuti kegiatan kepesantrenan termasuk pengajian kitab yang diadakan di masjid.

Sebelum masuk, calon santri diuji dalam tahap seleksi masuk pesantren. Walaupun dalam praktiknya, semua calon santri tetap diluluskan karena kenyataannya setiap tahun, santri baru yang mendaftar hanya berkisar 30-40 orang. Walaupun demikian, ujian seleksi ini sangat penting untuk memetakan kemampuan calon santri khususnya dalam keterampilan membaca Alquran.

\section{Kitab Kuning di Pesantren Putra Pusat Alkhairaat}

Pada awalnya, Pesantren Alkhairaat itu muat an kajiannya itu mengajarkan banyak muatan kitab kuning. Tradisi ini merupakan warisan dari Guru Tua yang sudah melahirkan banyak murid yang tersebar di Nusantara. Termasuk pada generasi awal pendirian pesantren yang mengacu sistem sekolah mu'allim yang diperuntukkan unt uk mencetak guru-guru yang ahli di bidang agama sesuai dengan yang tercantum pada misi pesantren. Konon muatan kurikulum mereka dulunya diakui oleh Universitas Azhar Mesir seperti halnya Pesantren Gontor Ponorogo yang juga menerapkan sistem Mu'allimin berdasarkan Surat Keputusan yang dikeluarkan oleh Lembaga Pendidikan Al-Azhar tanggal 19 April 1981 ("Lembaga Pendidikan Dan Dakwah Islam Alkhairaat," n.d.). Sehingga santri tamatan Pesantren dapat langsung melanjutkan studinya di Universitas Al-Azhar tanpa melalui tes muadalah (persamaan).

Kitab yang dikaji pada masa awal berdirinya pesantren ini pun cukup beragam yaitu terdiri dari kitab Khulashah Nurul Yaqin (Sejarah), Nahwu al-Wadhih, Matan Ajrumiyyah (Bahasa Arab), Aqidah al'Awwam (Akidah) , al-Mabadi, Fathu alQarib (Fikih), Riyadu al-Shalaih (Hadis), alSullam (Ushul Fiqh) dan lain sebagainya. Hanya saja, sejak mengikuti program pendidikan Madrasah di bawah naungan 
Kementerian Agama, secara langsung pesantren Alkhairaat mengadospi muatan kurikulum tersebut. Sehingga lambat laun tradisi kajian kitab yang kental khas nuansa pesantren menjadi terkikis.

Idealnya, Pesantren Alkhairaat Putra Pusat sebagai pesantren yang memiliki sejarah panjang dengan alumni yang sudah tersebar kemana-mana hingga ke luar negeri sekaligus cikal bakal pesantren Alkhairaat lainnya, seharusnya dijadikan sebagai percontohan bagi pesantren lainnya mengingat lokasi yang berdampingan dengan Kantor Pengurus Besar Alkhairaat.

Kini kondisi pesantren sangat jauh dari kualitas sistem yang mereka terapkan pada masa awalnya. Ini bisa dilihat dari kitabkitab yang diajarkan di pesantren. Secara umum kurikulum kepesantrenan terbagi ke dalam; Alquran, Hadis,Tauhid, Fikih, Bahasa Arab, Bahasa Arab, Mahfudzat dan Sejarah Alkhairaat. Pealajaran Alquran diajarkan di semua kelas, Tauhid dengan kitab Aqidah alAwam untuk kelas VIII dan IX. Mata Pelajaran Bahasa Arab diajarkan secara integratif dengan materi Sharaf dan Nahwu. Kitab pegangan yaitu Nahwu al-Wadhi dikombinasikan dengan Matan Ajrumiyyah. Namun, untuk saat ini dianjurkan juga untuk mengajarkan kepada santri buku "Cara cepat membaca Kitab Kuning”. Untuk hadis kelas VII yaitu kitab Mukhtaru al-Ahadis dan kelas IX Kitab Arba'in (tidak diajarkan secara langsung). Sementara, Akhlak hanya diajarkan di kelas VII dengan materi dari kitab Ta'lim Muta'allim.

Muatan kurikulum tersebut di atas sangat jauh jika dibandingkan dengan muatan kurikulum di pesantren Alkhairaat lainnya. Misalnya Pesantren Alkhairaat Madinatul Ilmu Dolo, justru kitab yang diajarkan lebih banyak seperti; Matan al-Asas wa al-Bina, alAmtsilah al-Tashrifiyyah, Nahwu al-Wadhi, Matan Aljrumiyyah, Kawakib al-Durriyyah (Qawaid), Tafsir Jalalayn, al-Itqan fi Ulumi al-Qur'an (Tafsir dan Ulumu al-Qur'an), alArba'in, Riyadhu al-Shalihin, Mukhtaru alAhadits, Al-Azkar li al-Nawawi (Hadis), AlQawa'id al-Asasiyyah fi ilmi Mustahalah alHadts (Ulumu al-Hadits), Safinatu al-Naja, alTahdzib fi Adillah Matni al-Taqrib,
Kifayatu al-Akhyar (Fikih) Kitab Ushul alFiqh li Abdi al-Wahhab Khallaf, Qawaidu alFiqhiyyah (Usul Fiqh), Talimu al-Muta'allim, Nashaihu al-Diniyyah (Akhlak), Khulasah Nurul al-Yaqin (Tarikh), dan al-Balagah alWadhihah (Balagah).

Pada dasarnya, pesantren di bawah naungan Alkhairaat kini tidak memiliki konsep kurikulum yang baku yang menjadi acuan, kecuali mata pelajaran: Sejarah Alkhairaat, Ajrumiyyah dan Bahasa Arab. Sisanya tergantung inovasi masing-masing pesantren cabang. Namun, pilihan kitab secara garis besarnya mengacu pada kitab-kitab yang bermazhab Syafi'iyyah dan berakidah Asy'ariyyah. Pilihan tersebut sudah menjadi tradisi di Alkhairaat layaknya pesantren tradisonal secara umum di nusantara yang mayoritas bermazhab Syafi'iyyah dan berakidah Asy'ariyyah. Bahkan dikisahkan, hingga kini masjid Alkhairaat di jalan Sis Aljufri tidak digunakan untuk pelaksanaan Salat Jumat, karena lokasinya berdekatan di antara Masjid Alkautsar di Kompleks Pesantren Putra dan Masjid Al-Nur dekat perempatan Jalan Sis Al-Jufri-Imam Bonjol.

Oleh karena tidak adanya acuan secara umum terkait kurikulum, maka otonomi dalam memilih materi maupun judul kitab diberikan kepada masing-masing pimpinan atau pembina pesantren di bawah naungan Alkhairaat sebagai penanggung jawab utama pengelolaan pesantren. Dalam praktiknya pun, terkadang seorang ustaz memilih kitab yang sendiri yang hendak diajarkan.

Habib Thalib pun sebagai pimpinan Pesantren Putra Alkhairaat Pusta Palu terkait pilihan kurikulum, memaparkan:

"Sebenarnya, kami punya konsep kurikulum sendiri. Hanya saja problem kami ada di tenaga pengajar. Yang mengajar kitab kuning hanya orang yaitu saya sendiri Ust. Thalib Aljufri, Ust. Ahmad Hadi al-Rumi, dan Abdullah Alatas. Ketiganya dibantu oleh seorang anak muda yang mengajar Qawaid di kelas yaitu Ust. Fadil." (Wawancara, Ustaz Habib Thalib al-Jufry, Pimpinan Harian Pesantren Putra Alkhairaat Palu, di Palu, 12/3/2018).

Habib Thalib sebagai pimpinan harian pun memendam cita-cita dengan mencanangkan konsep sistem pendidikan di 
Pesantren Putra Alkhairaat Pusat yang secara besar dibagi kedalam: tahsinu al-qira'ah, qira'atu al-kutub dan Bahasa Arab (muhadatsah). Untuk mewujudkan konsep ini, pimpinan pesantren sudah berkunjung ke Pesantren Al-Fatah Temboro Jawa Tengah untuk melakukan kerja sama dengan meminta tenaga pengajar di bidang Tahfiz. Disisi lain Ustaz Ahmad Hadi al-Rumi juga telah diut us untuk menjalin kerja sama dengan Pesantren Sidogiri, Pesantren Sunniyyah Salafiyah dan Darul Lugah Wa Dakwah di Pasuruan dengan tujuan yang sama agar pesantren tersebut memberi bantuan tenaga pengajar.

\section{Pembelajaran Kitab Kuning di Pesantren}

Secara umum, pembelajaran kitab di Pesantren Putra Alkhairaat Pusat dibagi menjadi dua bentuk. Sistem pertama yaitu pembelajaran yang dilaksanakan kelas dengan menggunakan metode klasikal (madrasi) (Qamar, n.d.). Sistem terintegrasi ke dalam kurikulum SMP yang mengacu pada kurikulum Dinas Pendidikan sebagai satuan pendidikan yang dibina. Mata pelajaran yang dipelajari dengan menggunakan kitab kuning sebagai sumber belajar yaitu Tauhid dengan Kitab 'Aqidah al-'Awwam, Hadis dengan Kitab 'Arbain serta Bahasa Arab dengan Kitab Matan Ajrumiyyah dan Nahwu alWadih. Khusus untuk pembelajaran bahasa Arab yang menggunakan dua kitab yang berbeda yang memiliki sistematika berbeda pula, sudah barang tentu secara metodolgis menyulitkan bagi santri pemula. Layaknya, mata pelajaran yang lainnya di kelas, sistem ini menggunakan media belajar yang tersedia di kelas seperti papan tulis, meja, kursi, kitab pegangan dan lain sebagainya. Khusus untuk kelas IX, pembelajaran dilakukan tanpa menggunakan bangku dan kursi layaknya tradisional yang menggunakan sistem halaqah karena keterbatasan sarana di kelas. Namun, situasi tidak menjadi penghalang dalam proses belajar mengajar.

Sistem ini madrasi sebenarnya memiliki kelebihan dari berbagai sisi, misalnya mampu memberikan materi ajar dalam jumlah santri yang banyak, ustaz bisa dengan mudah melatih kemampuan siswa khususnya dalam keterampilan membaca kitab melalui berbagai pertanyaan, baik secara lisan maupun yang tertulis di papan tulis.
Sehingga secara bertahap, ustaz bisa mengamati perkembangan pemahaman santri. Hanya saja, sistem ini membutuhkan keterampilan dan kerja keras dari ustaz untuk mengamati dan mengawasi para pola dan tingkah laku santri selama pembelajaran. Dalam kasus tertentu, terkadang ustaz lalai menegur santri yang tidak serius dan tidur selama proses pembelajaran.

Evaluasi pun dilaksanakan dalam waktu berkala untuk mengetahui sejauh mana penguasaan terhadap materi pembelajaran. Model evaluasi berupa tanya jawab secara berkala terkait materi, latihan (tamrinat) secara tertulis dengan soal-soal tertentu dan serta latihan i'rab untuk pelajaran qawaid. Sementara evaluasi secara umum dilaksanakan pada ulangan semester dua kali dalam setahun dengan sistem ujian tulisan berupa soal dalam bentuk essay. Hasil evalausi secara keseluruhan selama pembelajaran menjadi bahan pertimbangan dalam kelulusan/kenaikan kelas para santri. Walaupun dalam praktiknya, agak jarang santri tidak dinaikkan kelasnya mengingat pertimbangan santri yang sangat minim. Kasus tidak naik kelas hanya diberlakukan bagi santri yang betul-betul dianggap "nakal", banyak melanggar tata tertib pondok, dan jarang mengikuti kegiatan kepesantrenan seperti salat berjamaah, pengajian di masjid, zikir, maulid dan lain sebagainya

Sistem kedua yaitu pembelajaran kitab kuning di luar kelas dengan menggunakan metode halaqah dengan materi kitab fikih. Dalam sistem ini, santri dibagi ke dalam beberapa kelompok dengan tingkatan kitab yaitu: Risalah al-Jami'ah oleh Ustaz Habib Thalib Aljufry, Safinah al-Naja oleh Ustaz Habib Ahmad Hadi Rumi, dan Muqaddimah Hadhramiyyah oleh Ustad Habib Abdullah Alatas. Ketiga tenaga pengajar secara kualitas tidak diragukan lagi. Mereka di samping sebagai alumni pesantren, juga sebagai tamatan dari Darul Mustafa di Tarim Yaman.

Pembelajaran kitab di luar kelas biasanya dilaksanakan di masjid setelah Salat Magrib kecuali malam Kamis dan malam Jumat yang dilaksanakan sebelum salat Magrib. Pengelompokan santri dalam bentuk halaqah berdasarkan Kitab pada didasarkan kelompok kelasnya. Namun, dalam kasus 
tertentu apabila ada santri yang sudah dianggap cakap dan menguasai materi, maka ia akan dinaikkan ke tingkat kitab berikutnya. Begitu pula apabila ada santri yang memiliki memiliki kemampuan baca Alquran yang masih dianggap kurang cakap, maka dibina secara khusus oleh seniornya maupun ustaznya.

Metode halaqah ini berjalan secara sederhana tanpa menggunakan media layaknya pembelajaran di kelas kecuali kitab pegangan. Santri berkelompok melingkar di hadapan ustaz yang membina. Dalam praktiknya, pengajian dimulai dengan tadarus Alquran. Setiap santri secara bergiliran membaca 1-2 ayat. Ustaz lalu menyimak dan mengawasi bacaan santri. Apabila ada kesalahan dalam membaca, akan ditegur dan diperbaiki. Pelaksanaan tadarus ini biasanya menggunakan waktu kurang lebih 15 menit. Tujuan dari tadarus Alquran ini untuk semakin menguatkan dan memperbaiki bacaan (qira'ah) santri di samping dengan niat dan amalan sebelum memulai pengajian kitab. Berikutnya, dilanjutkan dengan pengajian kitab dengan materi sesuai dengan kelompok masing-masing. Proses pelaksanaan pengajian kitab dimulai dengan doa. Selanjutnya, ustaz melanjutkan kembali materi yang telah dibahas sebelumnya dengan membaca per kalimat, kemudian diterjemahkan dengan menggunakan bahasa Indonesia. Agar santri memahami konten kajian, setiap kalimat yang dianggap sulit dijelaskan oleh ustaz. Model halaqah ini menjadikan ustaz sebagai poros yang sangat aktif dalam pembelajaran, mendominasi sebagian besar waktu dengan membaca, menjelaskan, memberikan contoh atau perumpamaan hingga bertanya ke masing-masing santri terkait konten materi maupun bacaannya.

Selanjutnya, untuk menguji pemahaman santri, diberikan pertanyaan tertentu misalnya dalam pembahasan tentang "syarat salat", santri ditanya "apa boleh menggunakan pakaian yang berlubang menempel ke badan namun secara langsung kulit pemakai tak tampak di pandangan orang?". Apabila santri mampu menjawab pertanyaan yang diajukan, maka di sinilah peran ustaz kembali menjelaskan dan memberikan pemahaman. Tanya jawab secara langsung merupakan satu-satunya sistem evaluasi, karena pelajaran fikih dengan menggunakan sistem halaqah tidak diujikan langsung di sekolah seperti pelajaran kepesantrenan lainnya.

Kelebihan utama metode ini dibanding metode klasikal (madrasi) yaitu adanya hubungan yang lebih dekat antara ustaz dan santri, sehingga santri lebih rileks dalam menerima materi pembelajaran jauh dari nuansa ribut dan lelah. Diskusi terkait materi yang sedang diajarkan pun sangat cair. Santri lebih mudah menanyakan persoalan baik itu tidak berkaitan langsung dengan materi. Akibatnya santri lebih mudah memahami pelajaran walaupun tidak mempunyai struktur evaluasi bertahap seperti metode klasikal (madrasi).

\section{Problem dan Solusi Dalam Pembelajaran Kitab Kuning di Pesantren}

\section{Kaderisasi Tenaga Pengajar}

Pengalaman berbagai pesantren menunjukkan bahwa hidup mati sebuah pesantren ditentukan dengan keberadaan dan kualitas kader. Kelebihan utama yang dimiliki oleh kader pesantren adalah semangat mengabdi tanpa pamrih (ikhlas) sehingga tidak terlalu membebani pesantren. Sebagai hukum alam bahwa suatu generasi akan digantikan oleh generasi berikutnya. Oleh karena itu regenerasi kader sangat penting dilakukan termasuk tenaga pengajar.

Dalam hal kaderisasi, (Mastuki HS 2013, 55) menawarkan sistem kaderisasi modern dengan mengacu tahapan: a). Seleksi kader potensial b). Pendidikan umum dan khusus yang menunjang kebutuhan kader, c). Evaluasi bertahap, d). Pendidikan remedial bagi santri kader, e). Praktik magang, f). Sertifikasi kader untuk target terpenuhi atau tidak. Untuk memenuhi harapan it u, pesantren harus mengembangkan fungsi baru yaitu penyiapan kader. Salah satu upaya yaitu kerja sama dengan lembaga lain.

Pada masa awal berdirinya, Pesantren Alkhairaat Putra Pusat tidak mengalami kendala terkait tenaga pengajar karena sistem pendidikan yang dibangun yaitu sistem 
sekolah mu'allimin yaitu mencetak guru yang ahli di bidang agama. Sistem ini menuntut kepada alumni untuk mengabdikan dirinya mengajar minimal satu tahun di pesantren sebagai bentuk pengamalan atas ilmu yang telah diperoleh. Namun, setelah penghapusan sistem sekolah mu'allimin lalu beralih sistem madrasah dan sekolah umum dengan kurikulum mengacu pada kurikulum kementerian Agama dan Dinas Pendidikan, sistem pengabdian juga ikut hilang. Akibatnya, lambat laun tenaga pengajar yang ada terbawa usia sementara sistem kaderisasi yang berjalan lambat sehingga problem tenaga pengajar kini dirasakan oleh pesantren.

Problem tersebut semakin diperparah dengan realitas bahwa dua dari tiga orang ustaz yang mengajar di Pesantren Putra Alkhairaat Pusat Palu adalah Guru Pegawai Negeri Sipil. Walaupun merek adalah lulusan pesantren dan alumni dari Tarim Yaman. Namun, kultur mengajar di pesantren selama ini mereka kenal dengan sistem sorogan (talaqqi) ataupun bandongan (halaqah). Kedua sistem ini tidak mengenal embel-embel prosedural layaknya pembelajaran modern misalnya penyusunan silabus ataupun rencana pembelajaran. Karena kurang terbiasa dengan sistem tersebut, waktu mereka lebih banyak tersita pada urusan administrasi sebagai PNS dan sudah pasti mengurangi waktu untuk membina di pesantren. Habib Thalib al-Jufry mengungkapkan:

\footnotetext{
"Terus terang saya walaupun pimpinan pesantren juga diikat sebagai PNS. Karena diangkat di Kemenag, maka pagi harinya saya mencari jam di Madrasah, baru siang hari mengajar di Pesantren. Itupun dengan segala kerumitan administrasi." (Wawancara, Ustaz Habib Thalib al-Jufry, Pimpinan Harian Pesantren Putra Alkhairaat Palu, di Palu, 12/3/2018).
}

Oleh karena itu, Pesantren Alkhairaat perlu merancang program pembinaan kader, misalnya membiayai perkuliahan atau mengirim alumni untuk belajar ke luar negeri. Kelak mereka akan diharapkan bisa mengabdi total di pesantren. Hanya saja, program pengkaderan tersebut juga tidak mudah juga untuk dilaksanakan tanpa dukungan pihak terkait. Keterlibatan pihak terkait dari pemerintah (Kementerian Agama),Yayasan maupun pengurus Besar Alkhairaat sangat diperlukan.
Problem tenaga pengajar tersebut pada dasarnya juga berkorelasi dengan problem pendanaan yang dimiliki oleh pesantren. Menurut pengurus, pesantren tidak memiliki dana yang terlalu besar untuk membiayai pengajar kitab kuning. Realitas tersebut di atas tentu sangat memprihatinkan jika ditilik dari nama besar Alkhairaat yang telah melahirkan ribuan ahli agama yang tersebar di nusantara. Oleh karena, dibut uhkan pikiran ekstra keras dari pimpinan untuk mengatasi problem tenaga pengajar tersebut. Salah usaha yaitu menjalin kerja sama dengan pondok pesantren di Sidogiri dalam penyediaan tenaga pengajar. Hanya saja demi kesinambungan operasional dan kualitas pesantren, perlu juga dipikirkan ke depan terkait kaderisasi tenaga pengajar pesantren.

\section{Usaha Pengembangan Pesantren}

Pesantren sebagai lembaga pendidikan yang beroperasi secara full time dengan kata lain selama 24 jam penuh, sudah pasti membutuhkan tenaga dan biaya operasional yang tidak sedikit. Kesejahteraan tenaga pengajar, pengadaan dan perawatan sarana dan prasarana, biaya program maupun kegiatan rutin tak bisa terlaksana dengan baik tanpa dukungan manajemen dan biaya operasional. Oleh karena itu sebagai lembaga pendidikan swasta yang mandiri, setiap pesantren mestinya memiliki sumber pembiayaan dalam bentuk badan usaha.

Terkait dengan hal tersebut, Pesantren Alkhairaat putra tidak memiliki usaha yang bisa menopang operasional pesantren yang bisa diandalkan dalam menggaji banyak tenaga pengajar. Sumber dana lebih banyak mengandalkan bantuan dan Biaya Operasional Sekolah (BOS) dari pemerintah. Di samping itu juga, pengurus pesantren memungut pembayaran iuran bulanan sebesar Rp. 450.000 per bulan untuk tahun pelajaran 2017/2018, terdiri dari 150.000 /bulan dengan rincian Rp. 5.000, sisanya digunakan untuk biaya makan sehari.

Hanya saja, problem yang muncul kemudian ketika iuran bulan santri menunggak. Karena tidak semua santri berasal dari kalangan keluarga mampu. Di satu sisi, pengurus juga tidak bisa memaksa santri untuk melunasi pembayaran bulanannya. Di 
sisi lain, tidak bisa juga menaikkan pembayaran bulanan begitu saja.

Untuk mengatasi problem tersebut, pihak pesantren mencoba mengetuk hati para alumni untuk ikut terlibat dalam usaha pengembangan tersebut. Termasuk dalam penggalangan dana operasional pesantren maupun penciptaan badan usaha yang mampu menopang operasional pesantren. Dalam momen peringat an Haul Habib Abdullah bin Muhammad bin Idrus al-Jufry (Mantan Pimpinan Pesantren Putra Pusat Alkhairaat) tanggal 14 Maret 2018, organisasi alumni pesantren Putra Pusat Alkhairaat didirikan dengan nama Persaudaraan Alumni Babul Khairat. Di hari yang sama, pengurus inti organisasi alumni dikukuhkan. Organisasi ini diharapkan menjadi wadah bagi alumni dari berbagai profesi seperti pendidik, PNS, politisi dan lain sebagainya, untuk memberikan sumbangsih dalam pengembangan pondok.

\section{Tidak Memiliki Kurikulum Yang Baku}

Alkhairaat sebagai organisasi besar yang lahir dari lembaga Perguruan Islam Alkhairaat, seharusnya mempunyai standar kurikulum yang baku yang ditetapkan oleh Yayasan Alkhairaat. Standar kurikulum ini menjadi model untuk semua pesantren Alkhairaat di berbagai daerah. Namun faktanya, setiap pesantren Alkhairaat jalan sendiri-sendiri. Misalnya, sistem yang diajarkan di Pesantren Alkhairaat Putra Pusat berbeda dengan Pesantren Madinatul Ilmi Alkhairaat Dolo. Jika di Alkhairaat Pusat pembelajaran kitab masih sangat minim dengan hanya mengajarkan materi Fikih, Tauhid dan Nahwu, di Dolo justru bisa dikatakan sebagai percontohan Pesantren Alkhairaat dengan mengajarkan banyak materi seperti, Sharaf, Nahwu, Fikih, Tauhid, Tafsir, Hadis, Ulumul Quran, Ulumul, Hadis, Tarikh, dan Balagah.

Contoh lain dari perbedaan tersebut yaitu dalam pemilihan buku ajar (kitab), setiap pesantren menent ukan sendiri kitab apa yang mau diajarkan kepada santri tergantung dari kemauan gurunya, Misalnya, seorang ustaz di Pesantren Alkhairaat Madinatul Ilmi Dolo menambahkan materi Kitab Qawaid al-
Fiqhiyyah di kelas XII. Alasannya, ketika ia kuliah di Universitas Al-Azhar Mesir agak kesulitan mengikuti materi ini karena belum ia dapatkan sama sekali ketika mondok di pesantren Alkhairaat. Begitu pula, ia juga mengganti kitab Tauhid yang dianjurkan oleh pondok dengan kitab dari Universitas AlAzhar Mesir. Realitas ini bisa memunculkan problem apabila ustaz pada mata pelajaran tersebut diganti sehingga bisa jadi pelajaran yang diterima santri tidak berkesinambungan.

Ketidakseragaman yang lain yaitu pada pilihan satuan pendidikan yang dipilih. Jika, di Pesantren Pusat memilih satuan pendidikan SMP di bawah binaan Dinas Pendidikan, maka di Pesantren di Dolo justru memilih satuan pendidikan Madrasah mulai dari MI, MTs., hingga MA. Perbedaan sistem ini terjadi akibat otonomi penuh dari Yayasan Alkhairaat kepada pimpinan pesantren dalam mengelola pesantren. Dalam praktiknya, Yayasan hanya memiliki kewenangan mengangkat atau mengganti pimpinan. Sisi positifnya yaitu pimpinan mempunyai keleluasaan dalam berinovasi untuk pengembangan pesantren. Namun, problem yang muncul adalah ketika pesantren memiliki masalah yang sulit dipecahkan seperti dalam hal tenaga pengajar, maka koordinasi dengan Yayasan dan Pesantren menjadi kurang terjalin sehingga problem tersebut semakin besar.

Idealnya, Yayasan maupun Pengurus

Besar Alkhairaat membuatkan standar kurikulum Alkhairaat di tingkat pesantren pusat dan menjadi model untuk semua pesantren Alkhairaat di berbagai daerah. Di saat yang sama, Yayasan maupun Pengurus Besar Alkhairaat lebih memperhatikan perkembangan Pesantren Pusat Putra sebagai pesantren percontohan bagi pesantren Alkhairaat lainnya karena pesantren ini memiliki sejarah panjang dengan alumni yang sudah tersebar ke mana-mana hingga ke luar negeri.

\section{PENUTUP}

Kitab yang diajarkan di Pesantren Putra Pusat Alkhairaat masih pada pemula pada bidang Akidah dengan kitab Aqidatul Awwam, Fikih dengan Kitab Risalah al- 
Jamiah, Safinah al-Naja dan Muqaddimah Hadramiyyah, serta Qawaid Bahasa Arab (Nahwu dan Sharaf) dengan kitab Matan Ajrumiyyah. Muatan kitab yang diajarkan sangat jauh berbeda ketika masa awal pendirian di bimbingan Habib Muhammad bin Idrus Al-Jufry. Degradasi kualitas ini terjadi setelah pesantren mengakomodir secara penuh kurikulum pemerintah. Di satu sisi, pesantren kesulitan dalam mengombinasikan kurikulum pemerintah dengan kurikulum kepesantrenan khas Alkhairaat.

Metode yang digunakan di Pesantren Putra Pusat Alkhairaat sepertinya halnya pesantren kombinasi lainnya yang membuka satuan pendidikan sekolah/madrasah yakni menggunakan sistem klasikal (madrasi). Namun, mereka juga tidak mengabaikan metode tradisional halaqah di masjid yang justru dianggap lebih mudah dalam memberikan pemahaman keagamaan kepada santri dari pembelajaran kitab.

Kendala paling utama yang dihadapi pesantren dalam melaksanakan program pembelajaran kitab yaitu minimnya tenaga pengajar. Ini disebabkan karena pesantren tidak cukup memiliki dana yang besar dalam memberikan insentif kepada ustaz yang betulbetul siap mengabdikan hidupnya di pesantren. Sementara kendala dari sisi kurikulum tidak adanya standar kurikulum kepesantrenan yang harus diikuti oleh setiap pesantren di bawah naungan Yayasan Alkhairaat mengakibatkan kurikulum maupun kitab yang diajarkan bisa berubah sesuai selara pembina masing-masing. Akibatnya sulit mengukur keberhasilan pembelajaran dalam waktu jangka panjang.

Agar problem tersebut dapat diatasi, maka diperlukan untuk memperkaya kembali khazanah kajian kitab di Pesantren Alkhairaat dengan menambahkan kembali materi kitab dengan judul kitab yang lebih seperti pada masa awal berdirinya pesantren. Disisi lain, Kementerian Agama perlu mendorong pendirian Madrasah Diniyah Formal dengan kurikulum sebagian besar adalah kajian kitab kuning di samping memberikan bantuan kitab secara berkala.

Selanjutnya, pihak pesantren perlu meningkatkan kualitas tenaga pengajar terkait metode dan teknik kitab kuning serta memperkaya metode pengajaran tanpa mengurangi tradisi belajar seperti sorogan dan halaqah. Peningkatan ini kualiatas misalnya melakukan studi banding ke pesantren yang sudah memiliki sistem pembelajaran kitab kuning, mengikutkan ustaz dalam kegiatan pelatihan pembelajaran kitab kuning dan lain sebagainya. Adanya koordinasi antara Yayasan dan Pengurus Besar Alkhairaat terkait pengembangan baik secara finansial, tenaga pengajar maupun kurikulum dan mencarikan solusi yang dihadapi pesantren terkait hal tersebut. Di samping itu juga, Yayasan Alkhairaat diperlukan untuk merumuskan standar kurikulum berbasis kitab kuning yang harus dilaksanakan oleh setiap pesantren Alkhairaat agar memudahkan kontrol dan pengukuran kualitas pembelajaran kitab kuning di pesantren.

\section{UCAPAN TERIMA KASIH}

Terima kasih kepada seluruh pihak yang turut membantu terlaksananya penelitian ini. Terima kasih yang sedalamdalamnya kepada Kepala Balai Penelitian dan Pengembangan Agama Makassar yang menugaskan peneliti sehingga penelitian ini bisa terlaksana. Terima kasih juga kepada $\mathrm{Abu}$ Muslim dan Husnul Fahima Ilyas atas bimbingannya dalam pelaksanaan penelitian ini. Tak lupa pula terima kasih kepada Habib Thalib Al-Jufry (Pimpinan Harian Pesantren Putra Alkhairaat Pusat), Habib Ali Hasan AlJufry (Pimpinan Pesantren Madinatul Ilmi Alkhairaat Dolo), Habib Ahmad Hadi bin Muhammad Al-Rumi dan Habib Abdullah Alatas atas informasi yang diberikan sehingga memudahkan bagi peneliti dalam pengumpulan data penelitian.

\section{DAFTAR PUSTAKA}

Arsyad, Abdul Rahman. 2011. "Implementasi Pengajian Kitab Kuning Pada Pondok Pesantren Salafiyah Parappe Kabupaten Polewali Mandar." In Reinversi Kurikulum Dan Pembelajaran Pendidikan Agama Dan Pendidikan Keagamaan. Jakarta: Orbit.

As'ad, Muhammad. 1994. "Transformasi Kelekturan Pada Pesantren Manahil Ulum Kaballangan.” In Transformasi Kelekturan Pesantren Di Sulawesi Selatan. Ujung Pandang: Balai 
Peneletian Lektur Keagamaan Ujung Pandang.

Baso, Ahmad. 2012. Pesantren Studies $2 a$. Jakarta: Pustaka Afid.

Bruinessen, Martin Van. 2015. Kitab Kuning, Pesantren Dan Tarekat. Yogyakarta: Gading Publishing.

Burhanuddin, Jajat. 2012. Ulama Dan Kekuasaan: Pergumulan Elite Muslim Dalam Sejarah Indonesia. Jakarta: Mizan.

Cresswell, Jhon W. 2014. Research Design, Qualitative, Quantitative and Mixed Method Approaches. 4th Ed. California: SAGE Publications.

Dhofier, Zamakhsyari. 2011. Tradisi Pesantren: Studi Pandangan Hidup Kyai Dan Visinya Mengenai Masa Depan Indonesia. Jakarta: LP3ES.

E. Mulyasa. 2008. Standar Kompetensi Dan Guru Sertifikasi. Bandung: Remaja Rosda Karya.

Kambay, Sofjan B. 1992. Perguruan Islam Alkhairaat Dari Masa Ke Masa 1. Palu.

Kementerian Agama RI. 2017. Kementerian Agama RI Dalam Angka. Jakarta: Kementerian Agama RI Biro Hubungan Masyarakat, Data dan Informasi.

"Lembaga Pendidikan Dan Dakwah Islam Alkhairaat." n.d.

M, Abd. Kadir. 1994. "Transformasi Kelekturan Pada Pesantren As'adiyah Sengkang." In Transformasi Kelekturan Pesantren Di Sulawesi Selatan. Ujung Pandang: Balai Peneletian Lektur Keagamaan Ujung Pandang.

Mardiyah. 2013. Kepemimpinan Kiai Dalam Memelihara Budaya Organisasi. Yogyakarta: Aditya Media Publishing.

Mastuki HS. 2013. Manajemen Pondok Pesantren. Jakarta: Diva Pustaka.
Mujizatullah. 2011. "Implementasi Pengajian Kitab Pada Pondok Pesantren Mambaush Shalichin Al-Haramain." In Reinversi Kurikulum Dan Pembelajaran Pendidikan Agama Dan Pendidikan Keagamaan. Jakarta: Orbit. Muslim, Abu. 2016. "Problematika Pemanfaatan Buku Paket Pendidikan Agama Islam Sekolah Dasar Di Kota Balikpapan." Jurnal Edukasi 14.

Pusat Bahasa Departemen Pendidikan Nasional. 2008. Kamus Besar Bahasa Indonesia. Jakarta: Balai Pustaka.

Qamar, Mujammil. n.d. Pesantren: Dari Transformasi Metodologi Menuju Demokratisasi Institusi. Jakarta: Erlangga.

Rosdiana. 2011. "Implementasi Pengajian Kitab Pada Pondok Pesantren Salafiyah Ulumul Qur'an Fatimah Az-Zahra." In Reinversi Kurikulum Dan Pembelajaran Pendidikan Agama Dan Pendidikan Keagamaan. Jakarta: Orbit.

Subair, Muh. 2019. "Ideologi Kebangsaan dalam Pembelajaran Kitab Kuning di Pesantr $\neg$ En Pkp Manado." Al-Qalam. https://doi.org/10.31969/alq.v25i1.696.

Sugiyono. 2010. Metode Penelitian Pendidikan (Pendekatan Kualitatif, Kuantitatif, Dan R\&D). Bandung: Afabeta.

Tim Penulis. 2014. Sayid Idrus Bin Salim Al Jufry: Pendiri Alkhairaat Dan Kontribusinya Dalam Pembinaan Umat. Jakarta: Gaung Persada Press.

Umar, Nasaruddin. 2014. Rethinking Pesantren. Jakarta: Elex Media Komputindo. 